\title{
A superação da doutrina das "duas fontes"
}

\author{
Dr. Pe. Ari Luís do Vale Ribeiro
}

\section{RESUMO}

Este artigo estabelece em linhas gerais a superação da doutrina das Duas Fontes pela Constituição Dei Verbum do Concílio Vaticano II. Este artigo sumariza os passos da referida doutrina e a sua superação pelo Concílio Vaticano II (1962-1965).

Palavras-chave: Relação entre Escritura e Tradição. Revelação. Doutrina das Duas Fontes Concílio Vaticano II. Dei Verbum.

\section{ABSTRACT}

This paper outlines some considerations about the overcome of the Doctrine of Two Fountains by Const. Dei Verbum of Concil Vatican II (1962-1965). It summarizes the steps of the evolucion of this doctrine and it overcome by the Concil Vatican II.

Key Words: Relation between Scriptura and Tradition. Revelation. Doctrine of Two Fountains. Concil Vatican II. Dei Verbum.

\section{INTRODUÇÃO}

Testemunham a Revelação divina as Escrituras cristãs e a Sagrada Tradição. O Concílio Vaticano II (1962-1965), responsável pela renovação

\footnotetext{
Resumo da Tese apresentada em 12.03.2008 para a obtenção do grau de Doutor em Teologia Dogmática à Pontifícia Faculdade de Teologia Nossa Senhora da Assunção, sob a orientação do Côn. Prof. Dr. Antonio Manzatto.
} 
eclesial ocorrida a partir da segunda metade do séc. XX, professa a unidade intrínseca entre a Escritura e Tradição: “A Sagrada Tradição e a Sagrada Escritura estão portanto entre si estreitamente unidas e comunicantes. Pois promanam ambas da mesma fonte divina, formam de certo modo um só todo e tendem para o mesmo fim. [...] Por isso ambas devem ser aceitas e veneradas com igual sentimento de piedade e reverência" (DV 9).

Sabe-se que o primeiro e mais referencial debate da I sessão do Concílio Vaticano II (1962) foi sobre as "Fontes da Revelação" - Tradição e Escritura ${ }^{2}$.

Durante o Vaticano II, duas eram as opiniões dominantes acerca do tema da Revelação divina: os que defendiam a definição conciliar da Doutrina das "Duas Fontes" e os que a condenavam esperando do Concílio uma declaração sobre a Revelação divina mais próxima das prioridades do mesmo Concílio, ou seja, pastoral, ecumênico e dialogal. A doutrina das "Duas Fontes" estava eivada pela polêmica antiprotestante, ou seja, servia para a teologia católica rebater o princípio protestante Sola Scriptura.

A superação da doutrina das "Duas Fontes", operada pelo Concílio Vaticano II e pela sua Constituição Dei Verbum sobre a Revelação divina, não somente quis expressar a doutrina cristã numa perspectiva pastoral e ecumênica, como também não fez concessões, e não prendeu-se a compromissos diplomáticos ${ }^{3}$. Ao apresentar as relações entre a Tradição e Escritura, não de forma estanque, mas de forma mutuamente dependente e complementar, a Constituição Dei Verbum traduz com maior fidelidade a essência da Revelação divina que tem como centro e vértice a missão redentora de Jesus Cristo. Assim, Tradição e Escritura são apresentadas em mútua dependência e complementariedade: têm a sua origem em Deus, no devir da Igreja mutuamente se complementam e tendem para o mesmo fim (DV 7 e 8).

19. ${ }^{a}$ Congregação Geral em 14 de Novembro de 1962.

3 Era notável que no Concílio Vaticano II, a maioria dos Bispos ocidentais - os quais representavam a maioria dos Padres Conciliares - fora formada segundo a doutrina das "Duas Fontes", e que no primeiro período do Concílio, em 1962, praticamente rejeitou o esquema "De Fontibus Revelationes" preparado pela Comissão Teológica, o qual continha a doutrina das "Duas Fontes". O Papa João XXIII determinou então, a sua retirada do Concílio, e a constituição de uma Comissão mista, com membros da Comissão Teológica e do Secretariado para a União dos Cristãos, com o fim de elaborar um novo esquema. 
Não mais consideradas como fontes, Tradição e Escritura são modos, ou seja, expressões eclesiais da única fonte, que é o próprio Deus que Se revela, tendo como ápice deste processo o evento Jesus Cristo, com o mistério da sua encarnação, e o Seu Evangelho. Assim, a partir do Concílio Vaticano II e da sua Constituição Dei Verbum, Tradição e Escritura não são mais concebidas como fontes estanques da Revelação que se completariam materialmente. Tradição e Escritura se completam teologicamente, pois expressam o mesmo Evangelho anunciado por Jesus, que dá acabamento e caráter definitivo ao processo de Revelação. No tempo, ou seja, no devir da Igreja até a segunda vinda de Cristo, Tradição e Escritura se completam e se interpretam, anunciando o Evangelho de Cristo a humanidade.

Este tema parece silenciado, pois após a promulgação da Constituição Dei Verbum, e das diversas formas de sua recepção, a doutrina das "Duas Fontes" raramente é tratada. Tive a oportunidade de apresentar sumariamente a argumentação do assunto num artigo científico que versou sobre o conceito de Revelação nos Concílios de Trento e Vaticano II .

Perdeu-se o calor da questão e raramente se tem a ousadia de assinalar a solução que a Constituição Dei Verbum proporcionou, sobretudo no seu Capítulo II, que versa sobre "A transmissão da Revelação Divina", no qual apresenta as relações entre Tradição e Escritura sem o recurso da doutrina das "Duas Fontes", mas considerando-as mutuamente dependentes e complementares com a mesma origem e o mesmo fim. Por este motivo, inclusive o presente estudo quer apresentar academicamente a superação da doutrina das "Duas Fontes" pela Constituição Dei Verbum e as suas conseqüências teológicas.

\section{EVOLUÇÃO DA DOUTRINA DAS "DUAS FONTES"}

A doutrina das "Duas Fontes" da Revelação remonta aos Padres da Igreja mas ganhou expressão na teologia católica a partir da interpretação apologética e anti-reformadora dos Decretos do Concílio de Trento, especialmente o Decreto sobre os Livros Sagrados e as Tradições dos Apóstolos.

${ }^{4}$ RIBEIRO, A. L. V., A Revelação nos Concílios de Trento e Vaticano II. In: Teo n. 151, 2006, p. 55-74. 
Para o franciscano Van den Eynde que foi perito do Concílio Vaticano II, os Padres pré-nicenos: "... derivam do Novo e mesmo do Antigo Testamento toda a doutrina propriamente dita da Igreja, todos os pontos que são compreendidos naquilo que eles chamam a regra da verdade ou a pregação dos apóstolos. É certo que Ireneu invoca muitas vezes em favor da fé eclesiástica as palavras dos presbiteros e anciãos. Mas eles Ihe servem para confirmar, não para completar as verdades escriturísticas; ele mesmo acentua isso habitualmente"5.

Van den Eynde afirmava que o primeiro autor que menciona tradições doutrinais não-escritas (agrapha) é Clemente de Alexandria e acrescenta: "Mas acentuemos também que, na medida em que a tradição oral de Clemente ultrapassa o conteúdo das Escrituras, ela ultrapassa também a fé e a tradição das igrejas"

Para Tertuliano por exemplo, uma doutrina é falsa simplesmente porque não está nas Escrituras ${ }^{7}$. Segundo van den Eynde "Tertuliano apresenta a fé como coisa inseparável da Escritura: a modificação de uma traz consigo modificação de outra, e a intacta conservação da doutrina é impossível sem a integridade dos meios ou das fontes que servem para expô-la".

Tertuliano afirma a identidade da doutrina cristã com o ensinamento real e total da Escritura. Todos aqueles que reivindicam a verdade deverão pois, apelar aos documentos da verdade, à S. Escritura. A verdadeira fonte das heresias é a filosofia: "Tirai-lhes as idéias que Ihes são comuns com os pagãos para que resolvam suas questões unicamente mediante às Escrituras e já não poderão sustentar-se" 9 . Mas os cristãos possuem nas Escrituras, e não na filosofia, a fonte de sua fé: "A Igreja romana associa a lei e os profetas aos escritos evangélicos e apostólicos: é deles que ela haure sua fé (inde potat fidem)"10.

5 EYNDE, D., Les Normes de l'Enseignement Chrétien dans la Litttératura Patristique des trois premiers siecles, p. 122; apud KLOPPENBURG, B., A Defensibilidade da Suficiência Material da S. Escritura, p. 25.

6 Id., Ib., p. 275.

7 Cf. Adv. Hermog., 22.

8 Cf. EYNDE, D., o. c., p. 22; apud KLOPPENBURG, B., o. c., p. 25.

9 TERTULIANO, De carnis resurr., 3.

10 Id., De praescriptione, 36. 
Também o contemporâneo de Tertuliano, S. Hipólito de Roma tem o mesmo modo de falar. Ainda ele faz depender a fé cristã da integridade da S. Escritura: "há um só Deus que nós conhecemos pelas santas Escrituras. (...) Se quisermos adquirir a sabedoria deste mundo, só poderemos consegui-lo pela leitura das opiniões dos filósofos; assim também todos nós, que queremos exercer-nos na piedade, só poderemos fazê-lo mediante às palavras de Deus. Por conseguinte, saibamos tudo o que as Escrituras pregam, conheçamos tudo que elas ensinam. Creiamos como o Pai quer ser crido, glorifiquemos o Filho como Ele quer ser glorificado e recebamos o Espírito Santo como Ele quer ser dado. Esforcemo-nos em adquirir o conhecimento não segundo nossas preferências e sentimentos pessoais, violentando o que Deus nos concedeu, mas tal como Ele no-lo quis indicar nas santas Escrituras"11.

Os Santos Padres apoiavam a doutrina cristã sobre a Revelação divina, manifestada pelos profetas, por Cristo e pelos Apóstolos, identificando esta Revelação com as Escrituras do Antigo e do Novo Testamento. Todos admitem que entre a Revelação e Escritura haja perfeita harmonia que vai até a identidade de conteúdo; a voz de Deus ou a doutrina das Escrituras goza duma autoridade absoluta. Por isso, os Padres a apresentam como critério do verdadeiro ou do falso, como a única demonstração da fé e norma do ensinamento cristão ${ }^{12}$.

Geiselmann e Congar, na segunda metade do séc. XX e às vésperas do Vaticano II, identificam a mesma doutrina em S. Atanásio, S. João Crisóstomo, S. Jerônimo, Teófilo de Alexandria, S. Cirilo, S. Agostinho, S. Vicente de Lérins e S. Gregório Magno ${ }^{13}$.

Atribui-se a origem da doutrina das "Duas Fontes" a S. Basílio Magno (séc. IV) ${ }^{14}$. S. Basílio Magno dizia que Tradição era "ágrafos"15 isto é, não escrita e portanto, paralela à Escritura.

Na Idade Média e na Escolástica, os escritores eclesiásticos são incisivos em identificar a revelação divina e as verdades da fé cristã com a Sagrada

\footnotetext{
11 Adversus Noetum, 9

12 Cf. VAN DEN EYNDE, o. c., p. 130; apud KLOPPENBURG, B., o. c., p. 26.

13 Cf. KLOPPEnBURG, B., o. c., p. 26-27.

14 Cf. BOFF, Cl., Teoria do Método Teológico, p. 245.

15 Cf. CONGAR, Y La Tradizione e le Tradizioni, p. 18.
} 
Escritura. Na Idade Média "Teologia" e "Sacra Página" são simplesmente sinônimos; estudar a teologia significa estudar a Sagrada Escritura; "praticar a teologia" é crer na Escritura, explicá-la, defendê-la e tirar dela conclusões ${ }^{16}$. Desta forma, para os escolásticos a Escritura e a Teologia são uma coisa só, e a teologia está sempre centrada na Escritura.

Para S. Tomás de Aquino, Deus se revela na Escritura, mas o fiel a lê, por assim dizer, com os olhos da Igreja, que tem para isso especial assistência do Espírito Santo. Portanto, a Scriptura sola tomista não supõe o livre exame dos protestantes: crê também na autoridade da Igreja e a ela se submete. A veritas Scripturae e a doctrina Ecclesiae estão, assim, em perfeita concordância. S. Tomás e os escolásticos, em tese ou em teoria, defendem a suficiência da S. Escritura. Outro é o problema da aplicação prática deste princípio, quando se está diante de tradições apostólicas (usos, ritos e costumes) que não estão na $\mathrm{S}$. Escritura ${ }^{17}$.

S. Tomás de Aquino não tratou explicitamente da questão da Tradição, raramente usou tal termo, e é aplicado a S. Escritura ("Ex traditione sacrae Scripturae"; STh II- II, q. 140, a. 2; Contra Gentios, IV, c. 34) e aos Apóstolos ("Ex traditione apostolorum; STh III, q. 83, a. 4, ad 2).

De fato, em S. Tomás não se encontra nenhuma formulação explícita de uma doutrina da Tradição concebida como autônoma da verdade revelada, fonte integrativa e subordinada à Escritura.

Talvez, parcialmente, possa ser aplicado à Tradição o que S. Tomás diz a propósito da autoridade dos Padres da Igreja, uma autoridade (e então uma fonte) que ele julga essencial para o trabalho do teólogo e que ele mesmo valoriza muito, tanto que dela se serve freqüentemente nas suas argumentações teológicas.

Segundo S. Tomás, a teologia assume os seus princípios exclusivamente da S. Escritura (STh I, q. 1, a. 8, ad 2). Das sentenças dos Doutores da Igreja, a teologia se serve quase como de argumentos próprios, mas de um valor apenas provável $(I b$.). Estes argumentos não podem reclamar a mesma certeza daqueles que são diretamente da Revelação porque não fazem parte

16 Cf. DE VOOGHT, P., Les Sources de la Doctrine Chrétienne, p. 32; p. 148; cit. KLOPPNEBURG, B., o. c., p. 27.

17 Cf. KLOPPNEBURG, B., o. c., p. 29-30, inclusive nota 23. 
dos princípios infalíveis, como os da Palavra de Deus. Segundo S. Tomás, o argumento fundado sobre a autoridade dos Padres da Igreja tem um valor intermediário entre o dos argumentos fundados sobre o "locus firmissimus" da Escritura e o dos argumentos fundados sobre a autoridade dos filósofos, que são "argumentos externos e meramente prováveis" (Ib.).

Talvez, porém, dado o valor restrito e hipotético que S. Tomás confere à autoridade dos Padres da Igreja, é mais acertado não aplicá-los à Tradição quando afirma que o argumento da Tradição não deve ser misturado e confundido com o argumento patrístico.

Uma vez que S. Tomás aplica o termo Tradição apenas à Escritura e aos Apóstolos, deve-se concluir que a Tradição coincide com a Revelação e que, conseqüentemente, a Tradição é a fonte principal da Teologia e a sua autoridade tem valor absoluto e infalível ${ }^{18}$.

Com a Reforma, no séc. XVI, seu principal protagonista, o agostiniano Martinho Lutero, propõe como bandeira o postulado Sola Scriptura que seria o catalisador da simplicidade do Evangelho que a Reforma deveria vivenciar ${ }^{19}$. Contudo, com o postulado Sola Scriptura a noção de Revelação passava a ser identificada com a Escritura, ou seja, a Palavra de Deus estaria reduzida à Escritura. Tal postulado possuía também uma crítica à noção de Tradição, entendida como o retorno da Lei, o predomínio humano sobre a Palavra de Deus ${ }^{20}$.

Lutero identificou a "traditio" com "abusus", ou seja, com a lei humana pela qual o homem se esconde de Deus, e se levanta contra Ele para tomar nas mãos a tarefa de sua salvação em vez de esperá-la do Senhor. Isto significa que a Tradição era entendida como Lei no sentido paulino, e contraposta à graça de Deus. Lutero, então, ao redescobrir o Evangelho,

18 Cf. MONDIN, B., Tradizione, p. 609-610.

19 Cf. COMBLIN, J., A força da Palavra, p. 173ss.

20 Tal se pode ler no Discurso de Lutero na Dieta de Worms: "Sendo que Vossa Majestade e Graça Imperial desejam uma resposta simples, quero dá-la de forma não ofensiva nem agressiva: a não ser que seja convencido pelo testemunho da Escritura ou por argumento evidente (pois não acredito nem no Papa nem nos Concilios exclusivamente, visto que está claro que os mesmos erram e erraram muitas vezes e se contradisseram a si mesmos). A minha conviç̧ão vem das Escrituras a que me reporto, e minha consciência está presa à Palavra de Deus - nada consigo nem quero retratar porque é difícil, maléfico e perigoso agir contra a consciência. Deus que me ajude. Amém". 
pretendeu libertar a Palavra de Deus do Magistério eclesiástico que se apoderara desta Palavra e a empregava a seu bel-prazer, privando-a de sua força viva. Assim, a Reforma reduziu a Palavra de Deus à Escritura, identificando Tradição com o Magistério eclesiástico, negando e desconhecendo a originalidade de $\operatorname{ambos}^{21}$.

Da parte católica, a Doutrina das "Duas Fontes", após o Concílio de Trento, teve por finalidade reconhecer na transmissão escrita e oral da mensagem evangélica a mesma autenticidade que se dava à transmissão escrita. Com esta doutrina se quis justificar verdades ou práticas de fé que não estão claramente baseadas na Escritura ${ }^{22}$.

Esta distinção foi comparada pela Teologia posterior ao Concílio de Trento a dois "canais" através dos quais a Revelação era comunicada à Igreja, dando origem a uma espécie de dicotomia entre a Escritura e a Tradição (parte na Escritura - parte na Tradição).

O Concílio Vaticano II procurou corrigir esta "distorção" afirmando que há um só Evangelho, que é Cristo e, por isso, uma só "fonte" da Revelação (DV 9) sendo a Escritura e a Tradição, dois "modos" diversos de transmissão da Revelação (DV 7).

Os dois "modos de transmissão" do Evangelho não se distinguem entre si quanto à "quantidade" de verdades reveladas, mas quanto ao sentido formal da transmissão. A Revelação está toda na Escritura como está toda na Tradição, mas não da mesma forma, pois na primeira se apresenta como "norma positiva" que serve de ponto para reflexão da Igreja, enquanto na Tradição, se apresenta como "norma formal", que confere à Igreja a faculdade de expor, fielmente e sem erro, a mensagem evangélica que ela recebeu de Cristo.

O Concílio de Trento definira que a verdade revelada está nos livros escritos e nas tradições orais ${ }^{23}$. O Decreto tridentino sobre os Livros Sagrados

Cf.RATZINGER, J., Revelação e Tradição, p. 15-18.

22 Cf. BOFF, Cl., o. c., p. 245.

${ }^{23}$ "O sacrossanto, ecumênico e universal Concílio de Trento, legitimamente reunido no Espírito Santo sob a presidência dos três legados da Sé Apostólica, pondo-se perpetuamente ante seus olhos que, tirados os erros, se conserve na lgreja a pureza mesma do Evangelho que, prometido antes por obra dos profetas nas Escrituras Santas, promulgou primeiro por sua própria boca Nosso Senhor Jesus Cristo, Filho de Deus, e mandou logo que fosse pregado 
e as Tradições dos Apóstolos confessa que o Evangelho de Nosso Senhor Jesus Cristo é a única "fonte de toda salutar verdade e disciplina de costumes". Contudo, o Concílio de Trento não superou a ambigüidade do estatuto da Tradição em relação à Revelação divina, e permitiu um mal-entendido que persistiu na teologia pós-conciliar ${ }^{24}$ como se verá adiante.

Este texto foi retomado pelo Concílio Vaticano I na Constituição Dogmática Dei Filius, cap. II: "Esta revelação sobrenatural (...) está contida nos livros escritos e nas Tradições não escritas" (DZ 3006); e no cap. III : "Deve-se crer de fé divina e católica em tudo o que está contido na palavra de Deus escrita ou transmitida" (DZ 3011).

Nota-se que o Concílio Vaticano I colocou no mesmo plano as tradições não escritas e a "Tradição" no singular. Elas transmitem a "palavra de Deus" da mesma forma que a Escritura, mesmo que de modo diverso. Diversamente, no Concílio de Trento, as "tradições não escritas" referiam-se provavelmente, aos usos relativos às disciplinas ou às celebrações cultuais, consideradas dignas da veneração prestada à Escritura, porque mesmo que não provenham da Revelação, permanecem vivas na Igreja ${ }^{25}$.

Para exemplificar a exposição da Doutrina das "Duas Fontes", tomou-se o Manual de Teologia Dogmática, de J. Bujanda, SJ26.

"É de suma importância conhecer as fontes onde os fiéis vão buscar as verdades religiosas que praticam. Segundo os Concílios, Tridentino e Vaticano (I) a revelação sobrenatural foi-nos

pelo ministério de seus Apóstolos a toda criatura (Mt 28, 19s; Mc 16, 15) como fonte de toda salutar verdade e disciplina de costumes; e vendo que esta verdade e disciplina estão contidos nos livros escritos e nas tradições não escritas que, transmitidas como de mão em mão, chegaram até nós desde os Apóstolos que as receberam dos lábios de Cristo ou por inspiração do Espírito Santo; seguindo o exemplo dos Padres ortodoxos, com igual afeto de piedade e igual reverência recebe e venera todos os livros, do Antigo como do Novo Testamento, pois um só Deus é autor de ambos, e também as tradições mesmas que pertencem ora à fé ora aos costumes, como oralmente por Cristo ou pelo Espírito Santo ditadas e por contínua sucessão conservadas na Igreja Católica" (DZ 1501).

24 Cf. BOFF, Cl., o. c., p. 245.

25 Cf. HULL, R., The Concil of Trent and Tradition. In: The Eclesiastical Reviw 81, 1929, p. 469-482; 605-615; cit. BETTI, U., La dottrina de Concilio Vaticano II sulla trasmissione della Rivelazione, p. 10-11, nota 3.

${ }_{26}$ Trad. J. D. Oliviera. Porto: Liv. Apostolado da Boa Imprensa, 1958, 3. ${ }^{\text {a }}$ ed. 
transmitida em toda a sua integridade desde os Apóstolos, com os quais fica completa.

É esta revelação que o magistério autêntico, vivo e perene da igreja guarda, propaga, defende e explica dentro do seu verdadeiro sentido. Este magistério juntamente com a doutrina por ele proposta à nossa crença é, pois, a fonte primária ou imediata da qual mana toda a doutrina sobre a fé e costumes.

Mas, além desta fonte, existem, segundo ensinam os mesmos concílios, outras duas fontes da revelação: Tradição e Sagrada Escritura, nas quais essas mesmas verdades que a Igreja nos propõe, estão contidas. Chamam-se fontes mediatas ou remotas. Delas tratamos agora.

\section{ART. $1^{\circ}$ - A TRADIÇÃO}

Tese. A Tradição constitui uma das fontes da doutrina revelada por Jesus Cristo e pelos Apóstolos à Igreja.

Explicação. Tradição, em sentido amplo, é a transmissão oral ou escrita de um fato ou doutrina. No sentido estrito em que a tomamos, é a transmissão oral da doutrina revelada por Jesus Cristo e pelos Apóstolos à Igreja, independentemente da Sagrada Escritura. Pode por conseguinte, certa verdade encontrar-se nos livros sagrados e constar-nos ao mesmo tempo pela tradição.

Tem por objeto único a doutrina que Deus de um modo sobrenatural, manifestou ao gênero humano, e como meio de transmissão, aqueles por cujos atos essa mesma doutrina chega até nós, que por isso mesmo se costuma chamar órgão da Tradição.

Adversários. Os Protestantes em geral, que só admitem a Sagrada Escritura como fonte da revelação.

[...] Jesus Cristo que enviou os Apóstolos a ensinar tudo o que Ihes tinha mandado, não consta que deixasse por escrito uma só palavra; comunicouIhes a sua doutrina de viva voz.

Dos Apóstolos, só dois - S. Mateus e S. João - redigiram uma sucinta biografia de Jesus com parte dos seus milagres e doutrina. Além disso, es- 
creveu S. João três cartas e o Apocalipse; S. Pedro duas cartas; S. Tiago, uma; S. Judas, outra; S. Paulo, quatorze. Narram também a doutrina de Jesus e dos Apóstolos: S. Marcos e S. Lucas nos respectivos evangelhos, e S. Lucas também nos Atos dos Apóstolos. Estes escritos formam o Novo Testamento que abrange aproximadamente a quinta parte da Escritura. Tudo o mais que nas suas pregações ensinaram Jesus e os Apóstolos - alguns dos quais não deixaram escrito absolutamente nenhum - foi transmitida aos fiéis de viva voz.

E o mesmo S. Paulo nas suas cartas fala muitas vezes daquelas coisas que ensinam de viva voz, mandando que sejam guardadas e fielmente transmitidas aqueles que são aptos para ensinar os demais.

Por conseguinte, constatando a vontade de Cristo que se ensinasse à Igreja toda a sua doutrina, segue-se evidentemente, que a Tradição constitui uma fonte genuína da Revelação"27.

Este pequeno excerto de um Manual de Teologia anterior ao Concílio Vaticano II ilustra com bastante clareza a doutrina das "Duas Fontes". Notase em primeiro lugar, que Tradição e Escritura são apresentadas de forma estanque, quando afirma que a Tradição "em sentido amplo, é a transmissão oral ou escrita de um fato ou doutrina. No sentido estrito, em que a tomamos, é a transmissão oral da doutrina revelada por Jesus Cristo e pelos Apóstolos à Igreja, independentemente da Sagrada Escritura".

Na mesma exposição, notam-se as conseqüências teológicas da referida doutrina. O Magistério eclesiástico é apresentado como uma "fonte" da Revelação, como uma "fonte primária" e, conseqüentemente a Tradição e a Escritura são apresentadas como "fontes mediatas ou remotas".

Nota-se assim, uma primazia do Magistério eclesiástico na apresentação da mensagem evangélica. Isto significaria que o "contato seguro" dos fiéis com o conteúdo da Revelação divina se daria através do Magistério, a fonte primária, preferida à Escritura e à Tradição, as fontes "mediatas ou remotas". Com tal concepção, a teologia católica fez por merecer a crítica dos Reformadores que a acusavam de identificar a Tradição com o Magistério ${ }^{28}$.

27 BUJANDA, J., Manual de Teologia Dogmática, p. 106-108.

28 Cf. GOMES, C. F., A Revelação divina, p. 826; RATZINGER, J., o. c., p. 38. 
Por fim, nota-se como era típico neste tipo de Manuais de Teologia, considerar "adversários" os que discordavam de determinada doutrina. No caso, são apontados os "protestantes em geral"como oponentes desta doutrina, o que atesta o contexto de polêmica com os Reformadores que condicionou a consolidação da doutrina das "Duas Fontes".

Com esse excerto de um Manual de Teologia, elaborado sob a ótica da teologia pós-tridentina, podem ser reconhecidos os elementos principais da doutrina das "Duas Fontes", a qual remete para a questão da suficiência material da Escritura. Por este motivo, a seguir, ter-se-á a evolução da referida doutrina, assinalada pela questão da suficiência material da Escritura.

\section{A SUPERAÇÃO DA DOUTRINA DAS "DUAS FONTES" PELA CONSTITUIÇÃO DEI VERBUM}

"A sagrada Tradiçã, portanto, e a Sagrada Escritura estão intimamente unidas e compenetradas entre si. Com efeito, promanam ambas da mesma fonte divina, fazem como se fosse uma coisa só e tendem ao mesmo fim. A Sagrada Escritura é a palavra de Deus enquanto foi escrita por inspiração do Espírito Santo; a sagrada Tradição, por sua vez, transmite integralmente aos sucessores dos Apóstolos a palavra de Deus confiada por Cristo Senhor e pelo Espírito Santo aos Apóstolos, para que eles, com a luz do Espírito de verdade, a conservem, a exponham e a difundam fielmente na sua pregação; donde resulta assim que a Igreja não tira só da Sagrada Escritura a sua certeza a respeito de todas as coisas reveladas. Por isso, ambas devem ser recebidas e veneradas com igual espírito de piedade e reverência" (DV 9).

O parágrafo n. 9 da Constituição Dogmática Dei Verbum, especialmente a pequena expressão "promanam ambas da mesma fonte divina" assinala a superação da doutrina das "Duas Fontes".

O n. 9 se insere no cap. II da Constituição Dei Verbum que trata da "Transmissão da Divina Revelação", ou seja, da Sagrada Tradição. Os nn. 7 e 8 descrevem a Sagrada Tradição. Os parágrafos 9 e 10 tratam das relações entre Tradição, Escritura e Magistério. 
Este n. 9 assim se inicia: "A sagrada Tradição, e a Sagrada Escritura estão intimamente unidas e compenetradas entre si". Nota-se que a Tradição é citada antes da Escritura. Provavelmente esta disposição é cronológica, pois a Tradição precede a fixação da Revelação na Escritura. Mas há aqui uma precedência teológica, pois é através da Tradição que se dá a interpretação eclesial da Escritura ${ }^{29}$. Contudo, esta precedência não torna a Tradição superior à Escritura. Pelo contrário, o texto da Constituição Dei Verbum afirma a íntima unidade entre ambas: Tradição e Escritura coexistem "estreitamente conexas e interpenetradas". Isto implica que uma é necessária para a interpretação da outra.

O fato de a Tradição e a Escritura serem confessadas como "estreitamente conexas e interpenetradas" como diferentes expressões da mesma Palavra de Deus não resolve a questão da suficiência material da Escritura, tal qual foi posta antes e durante o Vaticano II, mas a ilumina, pois ambas, Tradição e Escritura são confessadas com origem divina comum, e que tendem para o mesmo fim de transmitir cada qual a seu modo, a Revelação divina. Mesmo que não se resolva a questão da suficiência material da Escritura, a questão é iluminada na medida em que se confessa que a Tradição não Ihe é paralela, mas íntima e ontologicamente ordenada, embora não possua o caráter da inspiração ${ }^{30}$.

A primeira frase introduz a seguinte, que é o tema da presente tese. Nela se professa que Tradição e Escritura "derivando ambas da mesma fonte divina" e que "formam de certo modo um só todo e tendem para o mesmo fim". Trata-se da não separação e da real distinção entre Tradição e Escritura. Aqui se nota não só a superação da doutrina das "Duas Fontes", presente no esquema "De Fontibus Revelationes" que se quis definir como dogma católico, mas também um reordenamento da teologia e de toda a Igreja para o seu centro que é o Evangelho de Cristo, a fonte da Revelação divina. E a motivação teológica de tal superação está na confissão da comum origem divina da Tradição e da Escritura, e que Deus dispôs que ambas fossem os meios da transmissão da Revelação ${ }^{31}$.

29 Cf. LATOURELLE, R., o. c., p. 388.

30 Cf. BETTI, U., o. c., p. 271.

31 Id., Ib., p. 269. 
Tem-se aqui um verdadeiro salto qualitativo que reflete toda a teologia conciliar e o avanço da mesma teologia em apresentar a Revelação divina da ótica da História da Salvação que tem seu cume em Jesus Cristo.

E porque Jesus é o centro da Revelação e da Igreja, que surge no acolhimento desta Revelação, a Constituição Dei Verbum reconhece Jesus Cristo e o seu Evangelho como a única fonte da mesma. Desta forma, Tradição e Escritura, mutuamente dependentes, têm em Cristo a sua única fonte e expressam cada qual a seu modo, o Evangelho de Cristo para a salvação da humanidade.

Em seguida, no n. 9 da Constituição Dei Verbum tem-se as definições de Escritura e Tradição, nos limites próprios do gênero literário conciliar que não devem ser tomadas sem as demais abordagens feitas às mesmas na referida Constituição.

A Escritura é "a palavra de Deus enquanto redigida sob a moção do Espírito Santo". O texto do n. 9 afirma que Tradição e Escritura "formam de certo modo um só todo e tendem para o mesmo fim". Isto significa que a Escritura, diferentemente da Tradição, é Palavra de Deus também na sua expressão, e é divinamente inspirada ${ }^{32}$.

A Tradição "transmite integralmente aos sucessores dos Apóstolos a palavra de Deus confiada por Cristo Senhor e pelo Espírito Santo aos Apóstolos para que, sob a luz do Espirito de verdade, eles por sua pregação fielmente a conservem, exponham e difundam". Não se diz que a Tradição é Palavra de Deus, mas que transmite a Palavra de Deus, pois não é divinamente inspirada, como o é a Escritura. Esta diferença põe a Tradição em um estado de inferioridade em relação à Escritura. Mas a Tradição transmite integralmente a Revelação, não só enquanto doutrina, mas como realidade ordenada à salvação ${ }^{33}$.

No n. 9 da Constituição Dei Verbum consta o acréscimo pedido pelo Papa Paulo VI, na IV Sessão do Vaticano II, citado anteriormente: "resulta assim, que não é somente através da Escritura que a Igreja deriva sua certeza a respeito de tudo o que foi revelado". Tal acréscimo, como alerta o jesuíta B. Sesboüé, deve ser lido, não segundo a doutrina das "Duas Fontes", mas

\footnotetext{
32 Id., Ib., p. 269-270.

33 Id., Ib., p. 270-271.
} 
segundo o conjunto deste II capítulo da Constituição Dei Verbum, ou seja, a partir da mútua dependência entre Tradição e Escritura ${ }^{34}$.

A última frase do n. 9 da Constituição Dei Verbum afirma que a Tradição e a Escritura "devem ser aceitas e veneradas com igual sentimento de piedade e reverência”. Tradição e Escritura não se identificam, mas se reclamam mutuamente. Por este motivo, os fiéis devem acolhê-las e venerá-las igualmente. Esta proposição implica a leitura da Escritura à luz da Tradição e, ao mesmo tempo, que a Escritura é o critério mais importante para o exame das tradições que testemunham e expressam a Sagrada Tradição.

Esta proposição se baseia no Decreto sobre a Revelação divina do Concílio de Trento, especialmente quando afirma que "seguindo o exemplo dos Padres ortodoxos, com igual afeto de piedade e igual reverência recebe e venera todos os livros".

O parágrafo n. 10, com o qual se conclui o segundo capítulo da Constituição Dei Verbum dedicado à Transmissão da Divina Revelação, ou seja, à Sagrada Tradição, é iniciado com a confissão de que a Tradição e a Escritura constituem o depósito da fé (depositum fidei). O depósito da fé foi confiado à Igreja, e a ele pastores e fiéis devem manter-se fiéis a fim de perseverar na essência da eclesialidade apostólica, assinalada pela referência a At 2, 42.

Assim sendo, a Igreja toda deve conservar, praticar e professar a fé recebida dos Apóstolos, a fim de que haja concordância entre pastores e fiéis. Para justificar esta proposição, a Constituição Dei Verbum se serve da Constituição Apostólica Munificentissimus Deus do Papa Pio XII, por ocasião da proclamação do dogma da Assunção de Nossa Senhora ${ }^{35}$, e de uma citação de S. Cipriano de Cartago: "A Igreja é o povo reunido ao sacerdote, e o rebanho unido ao seu pastor" (Ep. 6, 8).

A concordância entre pastores e fiéis, neste capítulo que trata da Tradição, introduz o tema do Magistério eclesiástico. De fato, no segundo parágrafo do n. 10 da Constituição Dei Verbum se professa que o múnus de interpretar autenticamente a Palavra de Deus, escrita ou contida na Tradição, foi confiado ao Magistério eclesiástico, cuja autoridade é exercida em nome de Jesus

34 Cf. SESBOÜÉ, B., o. c., t. IV, p. 441.

35 Cf. AAS 42, 1950, p. 756; ed. port.: Documentos de Pio XII, p. 509-510. 
Cristo. Temos aqui a confissão do Magistério segundo o Concílio Vaticano II: interpretar autenticamente a Palavra de Deus, a partir das expressões complementares entre si, da Palavra de Deus, Escritura e Tradição.

Em seguida, o Magistério é qualificado numa das perspectivas mais originais do Concílio Vaticano II, que é o serviço: o Magistério eclesiástico "não está acima da Palavra de Deus, mas a seu serviço, ensinando apenas o que foi transmitido, enquanto, por mandato divino e com a assistência do Espírito Santo, ouve a Palavra de Deus com amor, a guarda com todo cuidado, e neste único depósito de fé encontra tudo quanto propõe para se crer como divinamente revelado". Portanto, o Magistério eclesiástico, exercido pelo Papa e pelo Colégio dos Bispos, presta o serviço ao Povo de Deus de interpretar autenticamente a Palavra de Deus que antes foi ouvida e guardada, para ser proposta ao mesmo Povo.

Após a confissão sobre o Magistério eclesiástico como serviço de interpretar autenticamente a Palavra de Deus ao Povo se confessa a mútua dependência entre as três expressões da Palavra de Deus - Tradição, Escritura e Magistério - como se lê no n. 10 da Constituição Dei Verbum, onde também se professa a mútua interpenetração e a mútua dependência entre eles $^{36}$.

A Constituição Dei Verbum professa que esta mútua dependência é fruto do plano de Deus ao revelar-se à humanidade e não a uma simples articulação de elementos eclesiais. Tradição, Escritura e Magistério são, cada qual a seu modo, expressões da Palavra de Deus, mutuamente dependentes.

Desta mútua dependência entre Tradição, Escritura e Magistério confessa-se conseqüentemente, que um não subsiste sem o outro. Desta afirmação se conclui que o Concílio Vaticano II professa que nenhuma das expressões da Palavra de Deus se sobrepõe às outras. Cada qual a seu modo, expressa a única Palavra de Deus dirigida à humanidade, e cada qual não pode ser tomada separadamente, respeitando as suas diferenças e características. Cada uma delas expressa a única Palavra de Deus que

36 Cf. MOESCH, O., A Palavra de Deus, p. 48: “... as três formas: a Tradição, a Escritura e o Magistério, são de tal maneira interligadas e associadas que uma não têm consistência sem as outras. As três em conjunto, cada uma a seu modo, contribuem para a salvação. Cada uma é a seu modo Palavra de Deus". 
só terá a eficácia da sua expressão na medida em que cada uma das três estiverem devidamente articuladas entre si.

Assim, a interdependência entre Tradição, Escritura e Magistério, resolve a questão levantada por alguns teólogos protestantes que identificavam a noção católica de Tradição com o exercício do Magistério eclesiástico. Estas três realidades eclesiais, cada qual a seu modo, expressam a Palavra de Deus anunciada pela Igreja Católica. A mútua dependência entre ambas não permite a identificação de uma com outra, pelo contrário, mas a compreensão da originalidade de cada qual permite constatar a mútua subsistência entre ambas no exercício do múnus profético da lgreja.

\section{CONCLUSÃO}

A superação da Doutrina das "Duas fontes" permite abordar as relações entre a Tradição e Escritura que, embora mutuamente dependentes na sua origem, expressam o mesmo conteúdo, ou seja, o Evangelho de Cristo, e tendem para o mesmo fim, e cada qual é a medida para a interpretação da outra.

A doutrina das "Duas Fontes" da Revelação, tal qual se tem após o séc. $\mathrm{XVI}$, foi fruto de uma interpretação estreita do Decreto sobre a Escritura do Concílio de Trento, por supor a insuficiência material da Escritura, de forma que esta seria completada com a Tradição.

Tradição e Escritura são realidades eclesiais, mas não fontes da Revelação, ou seja, são modos de transmissão da mesma Revelação divina.

A Revelação tem como objeto o Deus mesmo que Se revela, e tem n'Ele a sua fonte. Assim sendo, as expressões da Revelação, a Tradição e a Escritura, tendo em Deus a sua fonte, são mutuamente dependentes e complementares, e cada qual a seu modo expressa a Palavra de Deus no tempo (DV 10).

Sobre a questão da superação da doutrina das "Duas Fontes" e das relações entre Tradição e Escritura reside a originalidade da Revelação cristã. O presente estudo se insere nesta preocupação, ou seja, expressar a originalidade da Revelação cristã a partir das relações entre Tradição e Escritura, expressões da Palavra de Deus, que não retorna aos céus sem produzir seus frutos na história (cf. Is 45, 23; 55, 10s) ao anunciar ao mundo 
através de Jesus Cristo, morto e ressuscitado, que nos dá a conhecer o amor de Deus Uno e Trino, que convida a humanidade a viver em comunhão Consigo, no tempo e na eternidade.

Nas plagas católicas, especialmente entre os latinos, a doutrina das "Duas fontes" foi assim difundida por quatro séculos e posta em xeque pelos estudos do Movimento Bíblico, bem como pela Teologia da História. Estes dois movimentos teológicos, surgidos no séc. XIX, e amadurecidos no séc. $\mathrm{XX}$, incidiram nos debates e nos documentos do Concílio Vaticano II e na renovação eclesial por ele proposta.

Os Movimentos de renovação eclesial (Patrístico, Litúrgico, Ecumênico, Missionário, Leigo, Teológico, Catequético, Social etc.) fizeram com que a compreensão teológica da Revelação cristã fosse ampliada para além de um elenco de verdades salutares para apreender o diálogo proposto por Deus com a humanidade na história, que teve seu vértice na encarnação do Filho de Deus, o Verbo divino.

O Movimento Bíblico, com suas Escolas, complementares entre si (Escola das Formas, Escola da Tradição, Escola da Redação) atestou com muita precisão a mútua dependência entre a Tradição e a Escritura, seja na redação da Escritura, seja na canonização dos Escritos inspirados, seja na interpretação eclesial dos mesmos, e permitiu compreender a mútua origem divina de ambas, bem como que ambas tendem para o mesmo fim. Esta mútua implicação, seja ontológica, seja histórica, permite reconhecer que Tradição e Escritura não são fontes da Revelação cristã, mas modos de expressão da mesma Revelação.

De fato, a tese de Geiselmann sobre o Decreto Tridentino e as relações entre Tradição e Escritura, como se viu no Cap. II, só poderia ter sido aceita se houvesse um contexto teológico para aceitá-la. E assim, se deu graças não somente ao Movimento Teológico, pois a tese de Geiselmann remonta a teólogos do séc. XIX e XX que o precederam, mas também graças aos Movimentos Bíblico e Patrístico que se debruçaram sobre o fenômeno da Tradição e sobre a sua qualificação teológica.

O primeiro argumento da Constituição Dogmática Dei Verbum para a superação da doutrina das "Duas fontes" reside na mútua origem da Tradição e da Escritura: "ambas promanam da mesma fonte divina". 
Graças à compreensão da unicidade do Evangelho é que se pode constatar que a Revelação divina possui nele, no Evangelho, a sua fonte, e que assim, Tradição e Escritura são suas expressões eclesiais.

A partir da unicidade da noção cristã de Palavra de Deus se pode apreciar o maior limite da doutrina das "Duas fontes", ou seja, apresentar a Revelação divina como um elenco de verdades salutares, com duas fontes paralelas, a Tradição e a Escritura, sendo que aquela era o complemento material desta, e sem se preocupar com a síntese orgânica entre ambas. É nesta síntese orgânica que se percebe a mútua implicação entre Tradição e Escritura.

Através da noção de depositum fidei viu-se que a Tradição divinoapostólica está consignada em um depósito, o qual foi custodiado à Igreja. O depositum fidei recebeu duas modalidades de existência: uma na fé viva da Igreja; outra no livro da Igreja objetivamente "acessível" aos fiéis. Estes modos de existir intimamente conexos entre si, têm a missão de transmitir a verdade revelada presente na Igreja a qual pôde desenvolver-se quer mediante a proclamação e a pregação das coisas cridas, quer mediante a transmissão aos pósteros e a explicação da Sagrada Escritura.

As noções de depósito da fé e senso da fé unidas à noção de regra da fé, assinalam a dinamicidade da Revelação cristã e da Igreja que a acolhe. Pode-se assim constatar que a Revelação não é apenas expressa em elencos de "verdades salutares", mas na vida da Igreja, que acolhe e testemunha a Palavra de Deus.

A doutrina das "Duas fontes" foi uma forma limitada de compreender a Tradição e a Escritura, bem como as suas mútuas relações, bem como o papel de ambas no processo da Revelação cristã e na vida da Igreja, onde a mesma Revelação é explicitada.

Esta doutrina tem as suas raízes nos Padres da Igreja e teve a sua expressão mais vigorosa na teologia pós-tridentina, fixando-se na teologia dos manuais, do século $X V I$ até o século $X X$. Através da presente tese se quis provar academicamente que a referida doutrina foi formalmente superada pelo Concílio Vaticano II e pela sua Constituição Dogmática Dei Verbum.

A "Doutrina das Duas Fontes" concebia Tradição e Escritura como entidades praticamente autônomas e estanques da expressão do Evangelho. A relação entre estas entidades se dava pela complementariedade material 
entre ambas. Esta compreensão supunha que o Evangelho poderia ser abordado a partir de um elenco de verdades salutares, contidas de forma disjuntiva, ou seja, ou Tradição ou na Escritura.

Os teólogos da Reforma afirmavam a suficiência da Escritura, tese não desconhecida por vários teólogos católicos. A Reforma protestante iniciada no século $\mathrm{XVI}$, foi a ocasião de polarização e de enrigecimento entre as partes. Frente os Reformadores que defendiam a suficiência da Escritura, e que acusavam os católicos de identificar a Tradição com o Magistério eclesiástico, e assim, de alterar a compreensão do Evangelho, a "Doutrina das Duas Fontes" serviu à Igreja católica, especialmente aos teólogos, para fazer frente aos Reformadores, sobretudo, para salvaguardar a Tradição e sua importância para a vida da Igreja.

Os Movimentos de renovação eclesial aprofundaram a noção de Revelação, cujos avanços foram em parte assimilados pelo Concílio Vaticano II e seus documentos, o que exigiu que os temas conexos fossem também melhor matizados. É neste contexto que se concebeu nova apresentação da Tradição, da Escritura e das suas relações.

A Constituição Dogmática Dei Verbum é um dos documentos mais importantes do Concílio Vaticano II, seja pela sua originalidade, seja pelas perspectivas teológicas e eclesiais por ela abertas. Parte-se de uma nova compreensão da Revelação cristã, a partir das perspectivas abertas pela Teologia da História, a qual favorece a compreensão unitária da mesma Revelação.

A Igreja Católica, através do Concílio Vaticano II, ao abrir mão da doutrina das "Duas fontes" e ao superá-la, optou por expressar com mais profundidade e precisão a essência da mesma Revelação e de seus elementos Tradição e Escritura. Assim, ao superar a doutrina das "Duas fontes," a Igreja conseguiu expressar com mais precisão o papel da Tradição e da Escritura na sua vida, bem como as relações entre ambas.

A doutrina das "Duas fontes" concebia a Revelação como um elenco de verdades salutares. Na verdade, dois eram os elencos de verdades salutares, a Tradição e a Escritura, materialmente insuficientes e complementares naquilo que um faltava ao outro. E, porque materialmente insuficientes, Tradição e Escritura eram assim, consideradas fontes da Revelação. Deve-se assim, notar o quanto a doutrina das "Duas fontes" foi dependente do ponto 
de vista "material" e que, graças aos Movimentos de renovação eclesial se pôde aprofundar o ponto de vista teológico da Tradição e a da Escritura sem descuidar do ponto de vista histórico e material, pelo contrário.

De fato, o Movimento Bíblico, ao debruçar-se sobre a redação da Escritura, suas etapas, formas, e fórmulas, bem como sobre a sua canonização, se depara com a Tradição.

Graças, também a outros Movimentos eclesiais, especialmente o Movimento teológico, percebeu-se que a Tradição é mais que um complemento material da Escritura, e que, tal qual esta, tem também origem divina.

De fato, através dos avanços dos Movimentos de renovação eclesial foi possível elaborar uma nova teologia da Tradição cristã e de sua relação com a Escritura. Concebe-se que ambas têm origem divina, e que ambas têm o mesmo fim. Concebe-se que Tradição e Escritura não são fontes paralelas da Revelação, mas modos de sua expressão, e intimamente implicados.

Esta mútua implicação se pode apreender a partir do papel eclesial da Escritura, desde a sua redação, a sua canonização, bem como a sua interpretação.

A redação da Escritura se deve ao carisma da inspiração que fixou a pregação apostólica recebida pela Tradição. Graças à mesma Tradição, a Igreja reconhece o carisma da inspiração em certos escritos e, assim, dá a conhecer a seus fiéis o cânon da Escritura.

Tanto na redação quanto na canonização da Escritura se percebe a importância da Tradição e da sua relação com a mesma Escritura. A transmissão do evento Jesus Cristo, no seio da Igreja, pela pregação apostólica, foi fixada pelos hagiógrafos nos escritos inspirados. No seio da mesma Igreja se deu a seleção e, assim, a canonização dos mesmos escritos inspirados.

A relação entre Tradição e Escritura vai ser também percebida na interpretação eclesial da Escritura. Com a assistência do Espírito Santo, os membros do Corpo de Cristo interpretam a Escritura na vida eclesial de forma que Tradição e Escritura se tornam norma de uma para a outra na peregrinação do Povo de Deus.

Assim, Tradição e Escritura estão totalmente implicadas: na origem e no fim, bem como na vida eclesial, uma em relação a outra, na elaboração, na canonização e na interpretação da Escritura. 
O Magistério eclesiástico recebeu do Concílio Vaticano II e em especial, da Constituição Dogmática Dei Verbum, um significativo ordenamento. Viu-se durante o desenvolvimento do presente trabalho que o Magistério eclesiástico não só estava ligado à questão da "Doutrina das Duas Fontes", mas era identificado com a Tradição, sobretudo pelos teólogos da Reforma.

O Magistério eclesiástico se insere na Tradição cristã, mas não se identifica com ela. O Magistério eclesiástico foi apresentado pelo Concílio Vaticano II como servo da Palavra de Deus que a ausculta, e que dela oferece a interpretação autêntica. Exercido pelo Colégio dos Bispos, que sucede o Colégio dos Apóstolos, o Magistério eclesiástico, assistido pelo Espírito de Cristo, guia a Sua Igreja para que seja fiel ao Seu Evangelho.

O exercício do Magistério eclesiástico é também um desdobramento das relações entre Tradição e Escritura. Neste desdobramento, se insere a questão do dogma. O Magistério eclesiástico ao elaborar os dogmas o faz com o recurso à Tradição e Escritura. Com relação ao recurso à Tradição e Escritura e à problemática da suficiência material da Escritura, viu-se que não há dogma proposto pelo Magistério eclesiástico cujo argumento não esteja embrionariamente presente na Escritura. Viu-se também que não há dogma que na sua elaboração não haja recurso à Tradição.

O Concílio Vaticano II e a Constituição Dogmática Dei Verbum não trataram da questão da suficiência material da Escritura, ou seja, se há alguma verdade de fé que não está na Escritura. No entanto, durante o desenvolvimento da presente tese, viu-se que nenhum dogma foi proposto pela Igreja sem recurso à Escritura. Desta forma, se constata que a Escritura contém, ao menos embrionariamente, todas as proposições da fé cristã, e que a Tradição que ilumina a interpretação da Escritura, atesta a sua suficiência teologal.

Assim, embora a questão da suficiência material da Escritura permaneça aberta, durante os passos deste estudo percebeu-se a suficiência noética, ou seja, na lógica da verdade, e a complementariedade qualitativa e não material (quantitativa) entre Tradição e Escritura.

A doutrina das "Duas fontes" foi posta em xeque pelo Concílio Vaticano II. A solução apresentada pela Constituição Dei Verbum desloca a atenção 
da questão das "Duas fontes" da Revelação para a noção de depósito da fé. É como se lê nos nn. $10^{37}$ e $21^{38}$ da mesma Constituição.

No n. 21 não ocorre o termo "depósito" mas "regra de fé", e assim se percebe que era desejo dos Padres conciliares do Vaticano II abordar Tradição e Escritura inseparavelmente unidas ontológica (mesma origem e mesmo fim) e historicamente (na vida da Igreja), através da noção de depositum fidei ${ }^{39}$.

O Papa João Paulo II, na sua Encíclica Fides et Ratio (1998), ao referirse à Palavra de Deus, servindo-se da Constituição Dei Verbum, afirmou:

“... a constituição Dei Verbum, depois de recordar que a palavra de Deus está presente tanto nos textos sagrados como na Tradição (DV 9-10), afirma sem rodeios: 'A Sagrada Tradição e a Sagrada Escritura constituem um só depósito sagrado da Palavra de Deus confiado à Igreja; aderindo a este, todo o Povo santo persevera unido aos seus Pastores na doutrina dos Apóstolos' (DV 10). Portanto, a Sagrada Escritura não constitui para a Igreja, a sua única referência; a 'regra suprema da sua fé' (DV 21) provém efetivamente da unidade que o Espírito estabeleceu entre a Sagrada Tradição, a Sagrada Escritura e o Magistério da Igreja, numa reciprocidade tal que os três não podem subsistir de maneira independente (DV 10)".

37 "A sagrada Tradição e a Sagrada Escritura constituem um só depósito sagrado da palavra de Deus, confiado à Igreja; aderindo a este, todo o Povo santo persevera unido aos seus pastores na doutrina dos Apóstolos e na comunhão, na fração do pão e na oração (cf. At 2, 42 gr.), de tal modo que, na conservação, atuação e profissão da fé transmitida, haja uma especial concordância dos pastores e dos fiéis [...] o encargo de interpretar autenticamente a palavra de Deus escrita ou contida na Tradição, foi confiado só ao Magistério vivo da Igreja, cuja autoridade é exercida em nome de Jesus Cristo. Este Magistério não está acima da palavra de Deus, mas sim ao seu serviço, ensinando apenas o que foi transmitido, enquanto, por mandato divino e com a assistência do Espírito Santo, a ausculta piamente, a guarda religiosamente e a expõe fielmente, haurindo deste depósito único da fé tudo quanto propõe à fé como divinamente revelado".

38 "A Igreja venerou sempre as divinas Escrituras como venera o próprio Corpo do Senhor não deixando jamais, sobretudo na sagrada Liturgia, de tomar e distribuir aos fiéis o pão da vida, quer da mesa da palavra de Deus quer do Corpo de Cristo. Sempre as considerou e continua a considerar, juntamente com a sagrada Tradição, como regra suprema da sua fé".

39 O mesmo se lê no Documento da Pontifícia Comissão Bíblica, no documento O Povo Judeu e as suas Sagradas Escrituras na Bíblia cristã (2001). 
Nota-se na argumentação de João Paulo II que não mais se confessa que a Revelação tem duas fontes, mas que a Palavra de Deus está presente tanto nos textos sagrados como na Tradição, e que Tradição e Escritura constituem um único sagrado depósito da Palavra de Deus.

Nota-se assim, que João Paulo II tinha em mente a polêmica doutrina das "Duas Fontes" e a solução apresentada pela Constituição Dei Verbum ao deslocar a atenção para o depósito da fé constituído pelos modos com os quais a Palavra de Deus se faz presente na Igreja, Tradição e Escritura, pois o Papa se serviu dos parágrafos Constituição Dei Verbum que tratam do depósito da fé, que acima se transcreveu (nn. 10 e 21).

De fato, João Paulo II tinha em mente a doutrina das "Duas Fontes", pois inseriu na sua argumentação o polêmico acréscimo que o Papa Paulo VI fez na última redação da Constituição Dei Verbum, "Portanto, a Sagrada Escritura não constitui para a Igreja a sua única referência”, (cf. DV 9) mas entendido no contexto de todo o Capítulo II da mesma Constituição.

A mesma ótica na abordagem das relações entre Tradição e Escritura se constata no Catecismo da Igreja Católica (1992) - que fala de uma fonte da Revelação divina (n. 80) - e no seu Compêndio (2005) ${ }^{40}$.

Estas considerações do Magistério eclesiástico, desde a Constituição Dei Verbum até o Compêndio do Catecismo da Igreja Católica assinalam como o Magistério trata a questão da Revelação divina e dos modos de se abordar a Palavra de Deus, Tradição e Escritura e as suas relações.

Há quem afirme que a doutrina das "Duas Fontes" se faz presente na Constituição Dei Verbum como jesuíta G. O'Collins ${ }^{41}$. O seu confrade B.

40 "A Tradição Apostólica realiza-se de duas maneiras: mediante a transmissão viva da Palavra de Deus (chamada também simplesmente a Tradição) e através da Sagrada Escritura que é o próprio anúncio da salvação transmitido por escrito. A Tradição e a Sagrada Escritura estão intimamente unidas e compenetradas entre si. Com efeito, ambas tornam presente e fecundo na Igreja o mistério de Cristo e provêm da mesma fonte divina: constituem um só sagrado depósito da fé, do qual a lgreja recebe a certeza acerca de todas as coisas reveladas. O depósito da fé é confiado pelos Apóstolos a toda a lgreja. Todo o povo de Deus, mediante o sentido sobrenatural da fé, conduzido pelo Espírito Santo, e guiado pelo Magistério da Igreja, acolhe a Revelação divina, compreende-a cada vez mais e aplica-a à vida".: Compêndio do Catecismo da Igreja Católica, nn. 13-15.

41 "Se bem que a Dei Verbum não eliminou a teoria das duas fontes, esta, todavia, é muito mais difícil de sustentar-se depois do Concílio Vaticano II, enquanto ela entende a Revelação divina primeiramente como auto revelação de Deus e sublinha fortemente a unidade 
Sesboüé reconhece que o final do n. 9 da Constituição Dei Verbum permite dupla interpretação ${ }^{42}$, ou seja, a opinião dos dois partidos tergiversantes até se legitimam, desde que não se invoque o Concílio em apoio da própria opinião em nível dogmático, e que se deve respeitar o centro de gravidade do Concílio que declara francamente a complementariedade qualitativa (e não quantitativa) entre Tradição e Escritura ${ }^{43}$.

O Catecismo da Igreja Católica (1992) parece trazer a questão entre Tradição e Escritura de forma amadurecida ao apresentá-las como "uma fonte comum ..." e "... duas modalidades de transmissão" (nn. 80-81). Notase, portanto, a superação da referida doutrina das "Duas Fontes" que aqui se quer provar, bem como a referência ao n. 9 da Constituição Dei Verbum que confessa uma só fonte da Revelação divina.

O Compêndio do Catecismo da Igreja Católica (2005), ao tratar das relações entre Tradição e Escritura, assim, se expressa: "A Tradição e a Sagrada Escritura estão em estreita ligação e comunicação entre si. Ambas, com efeito, tornam presente e fecundo na Igreja, o mistério de Cristo e brotam da mesma fonte divina: constituem um só sagrado depósito da fé, de onde a lgreja haure a própria certeza sobre todas as coisas reveladas" (n. 14).

O Catecismo da Igreja Católica e o seu o Compêndio, expressões do Magistério ordinário posteriores ao Concílio Vaticano II, tal qual a Constituição Dei Verbum, falam de uma só fonte divina da Revelação ${ }^{44}$.

entre Escritura e Tradição (DV 9)": O'COLLINS, Il ricupero della Teologia Fondamentale, p. 80-81.

42 Trata-se do acréscimo inserido no n. 9 por ordem do Papa Paulo VI a pedido do Coetus Patrum: "resulta assim, que não é através da Escritura que a Igreja deriva sua certeza a respeito de tudo o que foi revelado".

43 Cf. SESBOÜE, B., História dos Dogmas, t. 4, p. 440-442.

44 Numa perspectiva mais econômica, a Pontifícia Comissão Bíblica no documento O Povo Judeu e as suas Sagradas Escrituras na Bíblia cristã de 2001, assim se expressa: "Limites do contributo adicional da Tradição. Em que medida pode haver na Igreja cristã uma tradição que aumente a Palavra da Escritura? Trata-se de uma questão longamente discutida na história da teologia. O Concílio Vaticano II parece tê-la deixado em aberto, mas pelo menos evitou falar de 'duas fontes da revelação' que seriam a Escritura e Tradição. Afirmou, pelo contrário, que 'Tradição e Escritura constituem um único depósito sagrado da Palavra de Deus, confiado à Igreja' (DV 10). Afasta-se assim a idéia de uma tradição completamente independente da Escritura": PONT. C. BÍBLICA, O Povo Judeu e as suas Sagradas Escrituras na Bíblia cristã, p. 34-35. 
Pode-se também apreciar a superação da doutrina das "Duas fontes" em várias obras teológicas elaboradas após o Concílio Vaticano II $^{45}$.

A Igreja - através do Concílio Vaticano II - abriu mão da referida doutrina, pois avançou na compreensão da Revelação e de seus elementos constitutivos, e precisou das relações entre Tradição e Escritura no seio da Igreja. Assim, a Igreja confessa que Tradição e Escritura "promanam da mesma fonte divina" (DV 9), e que ambas "constituem um só depósito sagrado da palavra de Deus, confiado à Igreja; aderindo a este, todo o Povo santo persevera unido aos seus Pastores na doutrina dos Apóstolos e na comunhão, na fração do pão e na oração, de tal modo que, na conservação, atuação e profissão da fé transmitida, haja uma especial concordância dos pastores e dos fiéis" (DV 10).

Dr. Pe. Ari Luís do Vale Ribeiro

Doutor em Teologia Dogmática pela Pontifícia Faculdade de Teologia N. Sra. da Assunção/SP.

\section{BIBLIOGRAFIA}

BETTI, U. La dottrina de Concilio Vaticano II sulla trasmissione della Rivelazione. Milano: Massimo, 1966.

BOFF, Cl. Teoria do Método Teológico. Petrópolis: Vozes, 1999, 2ª . ed. revista. BUJANDA, J. Manual de Teologia Dogmática. Trad. J. D. Oliviera. Porto: Liv. Apostolado da Boa Imprensa, 1958, 3. ${ }^{a}$ ed.

Catecismo da Igreja Católica. S. Paulo: Loyola-Paulinas, 1999.

Compêndio do Catecismo da Igreja Católica. S. Paulo: Loyola-Paulinas, 2005.

45 Como exemplo, transcreve-se um excerto de M. Tábet: "Tradição e Escritura não são, portanto, duas vias independentes ou paralelas da Palavra de Deus: cada uma, pelo contrário, afirma a existência da outra, e sem uma, a outra ficaria irremediavelmente sujeita a arbitrariedade da subjetividade do pensamento. Certamente, uma e outra possuem uma própria identidade, determinada pelo modo ou forma em que transmitem a Revelação e, sobretudo, pela própria índole estrutural interna: enquanto a Bíblia possui as características de um texto escrito e, portanto, fixo e definitivo em si mesmo, a Tradição é uma realidade viva, chamada a crescer e desenvolver-se, não evidentemente por adição de realidades alheias ao conteúdo originário, mas pelo aprofundamento crescente do que no conteúdo originário estava só presente de modo implícito. Pode-se acrescentar que a Tradição, enquanto precede, acompanha e segue a Escritura, constituindo o seu contexto natural de interpretação, contém uma riqueza de conteúdo não de todo explícito na leitura histórico-crítica da Escritura, embora esteja na leitura cristológica": TÀBET, M., Introducción general a la Biblia, p. 46. 
COMBLIN, J., A força da Palavra. Petrópolis: Vozes, 1986.

CONGAR, Y. La Tradizione e le Tradizioni. Trad. G. Auletta. Roma: Paoline, 1961. Tit. Original: La Traditon et les Traditions (Paris, 1960).

GOMES, C. F. A Revelação divina - Perspectiva da Constituição Conciliar "Dei Verbum". In: REB XXVI, 1966, p. 816-837.

KLOPPENBURG, B. A defensibilidade da suficiência material da Sagrada Escritura. In: REB XXIII, 1963, p. 13-34.

LATOURELLE, R. Teologia da Revelação. Trad. F. C. Castro. S. Paulo: Paulinas, 1972.

MOESCH, O. A Palavra de Deus. Petrópolis: Vozes, 1995.

MONDIN, B., Tradizione. In: MONDIN, B. (ed.), Dizionario Enciclopedico del Pensiero di San Tommaso D'Aquino. Bologna: ESD, 1991, p. 609-610.

O'COLLINS, II ricupero della Teologia Fondamentale. Vaticano: LEV, 1996. Trad. L. Melotti. Tit. Original: Retrieving Fundamental Theology (New Jersey, 1993).

PONT. C. BÍBLICA, O Povo Judeu e as suas Sagradas Escrituras na Bíblia cristã. S. Paulo: Paulinas, 2002.

RATZINGER, J.; RAHNER, K. Revelação e Tradição. Trad. B. C. Silva. S. Paulo: Herder, 1968. Tit. original: Offenbarung und Uberlieferung (Freiburg, 1965); cotejada com a edição italiana de Morcelliana, Brescia, 2005.

RIBEIRO, A. L. V., A Revelação nos Concílios de Trento e Vaticano II. In: Teo n. 151, 2006, p. 55-74.

SESBOÜE, B., História dos Dogmas, t. 4. S. Paulo: Loyola, 2006. Tit. original: Histoire des Dogmes (Paris, 1996).

TÀBET, M. Introducción General a la Biblia. Trad. C. Bravo. Madrid: Palabra,

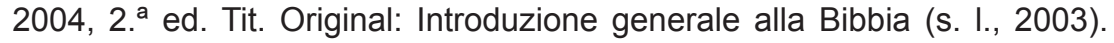

